University of Nebraska - Lincoln

DigitalCommons@University of Nebraska - Lincoln

Faculty Publications in Food Science and Technology

Food Science and Technology Department

July 2006

\title{
Chitosan Protects Cooked Ground Beef and Turkey Against Clostridium perfringens Spores During Chilling
}

Vijay Juneja

USDA-ARS, vijay.juneja@ars.usda.gov

Harshavardhan Thippareddi

University of Nebraska-Lincoln, harsha15@uga.edu

Latiful Bari

Natl. Food Research Inst., Food Hygiene Team, Kannondai-2-1-12, Tsukuba 305-8642, Japan

Yasuhiro Inatsu

Natl. Food Research Inst., Food Hygiene Team, Kannondai-2-1-12, Tsukuba 305-8642, Japan

Shinichi Kawamoto

Natl. Food Research Inst., Food Hygiene Team, Kannondai-2-1-12, Tsukuba 305-8642, Japan

See next page for additional authors

Follow this and additional works at: https://digitalcommons.unl.edu/foodsciefacpub

Part of the Food Science Commons

Juneja, Vijay; Thippareddi, Harshavardhan; Bari, Latiful; Inatsu, Yasuhiro; Kawamoto, Shinichi; and Friedman, Mendel, "Chitosan Protects Cooked Ground Beef and Turkey Against Clostridium perfringens Spores During Chilling" (2006). Faculty Publications in Food Science and Technology. 38.

https://digitalcommons.unl.edu/foodsciefacpub/38

This Article is brought to you for free and open access by the Food Science and Technology Department at DigitalCommons@University of Nebraska - Lincoln. It has been accepted for inclusion in Faculty Publications in Food Science and Technology by an authorized administrator of DigitalCommons@University of Nebraska - Lincoln. 


\section{Authors}

Vijay Juneja, Harshavardhan Thippareddi, Latiful Bari, Yasuhiro Inatsu, Shinichi Kawamoto, and Mendel Friedman 


\title{
Chitosan Protects Cooked Ground Beef and Turkey Against Clostridium perfringens Spores During Chilling
}

\author{
Vijay K. Juneja, Harshavardhan Thippareddi, Latiful Bari, Yasuhiro Inatsu, Shinichi Kawamoto, \\ AND MENDEL FriEDMAN
}

\begin{abstract}
We investigated the inhibition of Clostridium perfringens spore germination and outgrowth by the biopolymer chitosan during abusive chilling of cooked ground beef $(25 \%$ fat) and turkey $(7 \%$ fat) obtained from a retail store. Chitosan was mixed into the thawed beef or turkey at concentrations of $0.5 \%, 1.0 \%, 2.0 \%$, or $3.0 \%$ (w/w) along with a heat-activated 3 -strain spore cocktail to obtain a final spore concentration of 2 to $3 \log _{10} \mathrm{CFU} / \mathrm{g}$. Samples $(5 \mathrm{~g})$ of the ground beef or turkey mixtures were then vacuum-packaged and cooked to $60{ }^{\circ} \mathrm{C}$ in $1 \mathrm{~h}$ in a temperature-controlled water bath. Thereafter, the products were cooled from 54.4 to $7.2{ }^{\circ} \mathrm{C}$ in $12,15,18$, or $21 \mathrm{~h}$, resulting in 4.21, 4.51, 5.03, and $4.70 \log _{10} \mathrm{CFU} / \mathrm{g}$ increases, respectively, in $C$. perfringens populations in the ground beef control samples without chitosan. The corresponding increases for ground turkey were 5.27, 4.52, 5.11, and 5.38 $\log _{10} \mathrm{CFU} / \mathrm{g}$. Addition of chitosan to beef or turkey resulted in concentration- and time-dependent inhibition in the C. perfringens spore germination and outgrowth. At $3 \%$, chitosan reduced by 4 to $5 \log _{10} \mathrm{CFU} / \mathrm{g} C$. perfringens spore germination and outgrowth $(P \leq 0.05)$ during exponential cooling of the cooked beef or turkey in 12,15 , or $18 \mathrm{~h}$. The reduction was significantly lower $(P<0.05)$ at a chilling time of $21 \mathrm{~h}$, about $2 \log _{10} \mathrm{CFU} / \mathrm{g}$, that is, $7.56 \log _{10}$ $\mathrm{CFU} / \mathrm{g}$ (unsupplemented) compared with $5.59 \log _{10} \mathrm{CFU} / \mathrm{g}$ (3\% chitosan). The results suggest that incorporation of $3 \%$ chitosan into ground beef or turkey may reduce the potential risk of $C$. perfringens spore germination and outgrowth during abusive cooling from 54.4 to $7.2{ }^{\circ} \mathrm{C}$ in 12,15 , or $18 \mathrm{~h}$.

Keywords: beef, chilling, chitosan, Clostridium perfringens, growth inhibition, turkey
\end{abstract}

\section{Introduction}

C lostridium perfringens continues to remain a major cause of foodborne illness. Improper storage and/or inadequate cooling practices in retail food operations have been cited as a cause of food poisoning for $97 \%$ of C. perfringens outbreaks (Bean and Griffin 1990; Kalinowski and others 2003; Taormina and others 2003). According to the Centers for Disease Control and Prevention, the pathogen accounted for $3.2 \%$ cases of food poisoning and $2.1 \%$ of the outbreaks from 1993 to 1997 (CDC 2000). Foods associated with such outbreaks include cooked meat and poultry products (Bryan and McKinley 1979; Bryan 1988). Such foods are likely to be mishandled in an institutional food service setting, where these products may be prepared a day in advance and may be cooled at a slow rate or these products are not adequately refrigerated. These conditions favor germination and outgrowth of surviving, heat shocked C. per-

MS 20060028 Submitted 1/15/2005, Accepted 5/30/2006. Author Juneja is with Microbial Food Safety Research Unit, Eastern Regional Research Center U.S. Dept. of Agriculture, Agricultural Research Service, 600 E. Mermaid Lane, Wyndmoor, PA 19038, U.S.A. Author Thippareddi is with Dept. of Food Science and Technology, Univ. of Nebraska-Lincoln, Lincoln, NE 68583, U.S.A. Authors Bari, Inatsu, and Kawamoto are with Natl. Food Research Inst., Food Hygiene Team, Kannondai-2-1-12, Tsukuba 305-8642, Japan. Author Friedman is with Western Regional Research Center, U.S. Dept. of Agriculture, Agricultural Research Service, Albany, CA 94710, U.S.A. Direct inquiries to authorJuneja (E-mail: vjuneja@errc.ars.usda.gov).

Mention of trade names or commercial products in this publication is solely for the purpose of providing specific information and does not imply recommendation or endorsement by the U.S. Dept. of Agriculture. Mention of a trade name, proprietary products, or company name is for presentation clarity and does not imply endorsement by the authors of the Univ. of Nebraska. fringens spores into high numbers of vegetative cells. These cells are typically responsible for the reported illnesses. It is, therefore, important to cool and refrigerate foods quickly after cooking.

Products meeting the compliance guidelines for cooked, uncured, ready-to-eat (RTE) meat and poultry have not been linked to C. perfringens illness. The guidelines specify the cooling of cooked, uncured meat and poultry products from 54.4 to $26.7^{\circ} \mathrm{C}$ in $1.5 \mathrm{~h}$ and from 26.7 to $4.4^{\circ} \mathrm{C}$ within $5 \mathrm{~h}$ (preferred) or from 48.9 to $12.8^{\circ} \mathrm{C}$ within $6 \mathrm{~h}$ (alternative), followed by additional cooling to $4.4^{\circ} \mathrm{C}$ before packing (USDA/FSIS 2001). For cooked, cured meat and poultry products, the guidelines allow cooling from 54.4 to $26.7^{\circ} \mathrm{C}$ in $5 \mathrm{~h}$, and from 26.7 to $7.2{ }^{\circ} \mathrm{C}$ in $10 \mathrm{~h}$. Cooling process deviations may occur in the food processing industry due to electrical outage or refrigeration equipment failure. In case of cooling deviations, USDA/FSIS requires that the relative growth of $C$. perfringens not exceed $1.0 \log _{10} \mathrm{CFU} / \mathrm{g}$ during the cooling of certain meat and poultry products (USDA/FSIS 2001). In view of the potential hazards associated with the cooling of cooked foods, adding safe and effective antimicrobials to meat and poultry products can insure safety when the rate and extent of cooling of cooked products is not adequate.

Chitin, a component of the exoskeletons of insects and crustaceae including crab and shrimp, consists of $N$-acetylglucosamine residues joined by $\beta$ (1-4) glycosidic links. It is the 2nd most abundant biopolymer in the world after cellulose. Structurally, chitin (poly- $N$-acetylglucosamine) resembles cellulose, except that the substituent at the carbon-2 atom is an acetylated amino (-NH-CO$\left.\mathrm{CH}_{3}\right)$ instead of a hydroxyl $(\mathrm{OH})$ group. Deacetylation is achieved by exposing chitin to strong $\mathrm{NaOH}$ solutions or to the enzyme chitosinase (Figure 1). Interest in chitin resides in the fact that its 
deacetylated product called chitosan exhibits desirable functional and biological traits, including antimicrobial properties and the fact the biopolymer has received generally-accepted-as-safe (GRAS) status in the United States (Anonymous 2001).

Chitosan exhibits antimicrobial effects against a variety of pathogenic and spoilage organisms (see reviews by Rabea and others 2003; and Roller 2003). These include (a) spoilage and pathogenic microorganisms in meat (Darmadji and Izumimoto 1994); (b) spoilage microorganisms in chilled pork (Sagoo and others 2002); (c) waterborne coliform pathogens (Chen and others 2002); and (d) microorganisms adhered to stainless steel surfaces (Knowles and Roller 2001). Related studies on the antimicrobial effects of chitosan, chitosan derivatives, and chitosan films are described elsewhere (Ouattara and others 2000; Rhoades and Roller 2000; Jumaa and others 2002; Tsai and others 2002; Kim and others 2003; Nychas and others 2003; and Pranoto and others 2005). Generally, chitosan is more effective against gram-negative than against gram-positive bacteria (Devlieghere and others 2004). The polymer also protected mice against infection by Listeria monocytogenes (Okawa and others 2003), suggesting that the antimicrobial action may also occur in humans.

Because chitosan has not been previously evaluated for its ability to control C. perfringens in meat and poultry and because it is widely used as a food additive and in pharmaceutical formulations (Hirano 1997; Shepherd and others 1997; Shahidi and others 1999; Singla and Chawla 2001; Roller 2003), the major aim of this study was to explore its potential to control or inhibit outgrowth of $C$. perfringens from spores in ground beef and ground turkey during extended rate and extent of cooling after sous vide cooking.

\section{Materials and Methods}

\section{Test compound}

Chitosan glutamate, a deacetylated derivative of chitin, was obtained from Pronova Biopolymer (Drammen, Norway). This com-

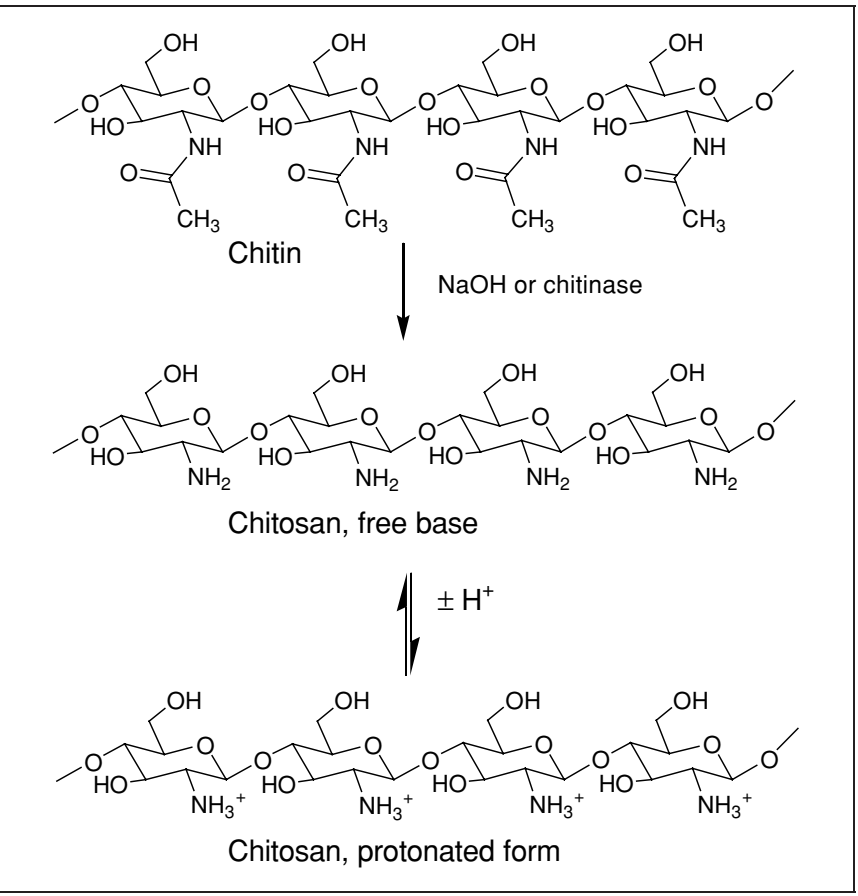

Figure 1-Deacetylation of chitin to chitosan and acidbase equilibrium of chitosan. The antimicrobial effect of the free base is postulated to involve chelation to trace elements and metalloenzymes, and of the protonated form to disruption of cell membranes. See text. pound contained $42 \%$ glutamic acid and had $86 \%$ degree of deacetylation (information provided by the manufacturer).

\section{Test organisms and spore production}

Three strains of $C$. perfringens, NCTC 8238 (Hobbs serotype 2), NCTC 8239 (Hobbs serotype 3), and NCTC 10240 (Hobbs serotype 13), were obtained from the Microbial Food Safety Research Unit culture collection (Wyndmoor, Pa., U.S.A.). C. perfringens spores were produced in modified formulation of the Duncan and Strong sporulation medium as described previously (Juneja and others 1993). Briefly, the spore crop of each strain was washed twice with sterile distilled water and then resuspended in sterile distilled water. The suspensions were stored in a refrigerator at $4{ }^{\circ} \mathrm{C}$. Spore population was enumerated by spiral plating (Spiral Biotech, Bethesda, Md. U.S.A.; Model D) of appropriate dilutions (in $0.1 \%$ peptone water), in duplicate, on tryptose-sulfite-cycloserine agar without cycloserine, that is, SFP agar (Difco, Detroit, Mich., U.S.A.) followed by incubation of plates anaerobically for $48 \mathrm{~h}$ at $35^{\circ} \mathrm{C}$. A spore cocktail was prepared immediately prior to experimentation by mixing equal numbers of spores of $C$. perfringens from each of the 3 suspensions. This composite of spore strains was heat-shocked for 20 min at $75^{\circ} \mathrm{C}$ prior to use.

\section{Preparation and inoculation of meat}

Ground beef ( $25 \%$ fat) or turkey ( $7 \%$ fat) was obtained from a local retail market and frozen $\left(-5^{\circ} \mathrm{C}\right)$ until use (approximately $40 \mathrm{~d}$ ) Chitosan was mixed into all ground beef or turkey samples with a Hobart mixer to final concentrations of $0.5 \%, 1.0 \%, 2.0 \%$, or $3.0 \%(w / w)$ Duplicate ground beef or turkey (5-g samples) was then aseptically weighed into low-oxygen transmission Whirl Pak bags (4-oz/120mL capacity; $3^{\prime \prime} \mathrm{W} \times 71 / 4^{\prime \prime} \mathrm{L} ; 7.5 \mathrm{~cm} \times 18.5 \mathrm{~cm}$; barrier film $0.125 \mathrm{cc}$ oxygen transmission per 100-in. square in $24 \mathrm{~h}$ [Part nr B01298WA Nasco, Modesto, Calif., U.S.A.]) and inoculated with $1 \mathrm{~mL}$ of the heat-shocked C. perfringens spore cocktail to a final concentration of spores was approximately $3.0 \log _{10} \mathrm{CFU} / \mathrm{g}$. The bags were thoroughly mixed manually to ensure even distribution of the spores in the meat sample. Negative controls consisted of bags containing noninoculated ground beef or turkey. The bags were then evacuated to a negative pressure of 1000 millibars and heat sealed using a Multivac gas-packaging machine (Model A300/16, Multivac Inc. Kansas City, Mo., U.S.A.).

\section{Cooking and cooling procedures}

The bags containing inoculated products were sandwiched between stainless steel wire racks as described elsewhere (Thippareddi and others 2003) and submerged completely in a circulating water bath (Exacal, Model RTE-221, NESLAB Instruments, Inc., Newington, N.H., U.S.A.). The temperature of the water bath was increased to $60{ }^{\circ} \mathrm{C}$ in $1 \mathrm{~h}$. The bags were then removed, chilled immediately in an ice water bath, and plated as described below. A 2nd set of racks containing the products for each treatment was cooked and transferred to the programmable water bath set at $54.5^{\circ} \mathrm{C}$. The bath equilibrated at this temperature for $10 \mathrm{~min}$ and then chilled at an exponential rate from 54.5 to $7.2^{\circ} \mathrm{C}$, according to the target chilling times depicted in Figure 2.

\section{Enumeration of bacteria}

Immediately after cooking and/or chilling, samples were removed and enumerated for total germinated $C$. perfringens population by spiral plating on tryptose-sulfite-cycloserine (TSC) agar as described previously (Juneja and Marmer 1998). The tota C. perfringens population was determined after $48 \mathrm{~h}$ incubation at 
$37^{\circ} \mathrm{C}$ in a Bactron anaerobic chamber (Bactron IV, Sheldon Laboratories, Cornelius, Oreg., U.S.A.). The lower limit of detection by this procedure is $21 \mathrm{CFU} / \mathrm{mL}$. Both uninoculated raw beef and cooked beef ( $25 \mathrm{~g}$ ) were used to verify the absence of naturally occurring C. perfringens. This variation involved the use of lactose-gelatin and nitrate-motility medium (Schwab and others 1984).

\section{Statistical analyses}

Two independent trials, each performed in duplicate, as defined by a new batch of meat, were performed for each of the exponential chilling rates $(12,15,18$, and $21 \mathrm{~h})$. Data were analyzed by analysis of variance using the SAS General Linear Model procedure (SAS Inst., Inc., Cary, N.C., U.S.A.; Release 8.01). Bonferroni LSD method was used to separate means of the $C$. perfringens populations $\left(\log _{10}\right.$ CFU/g) (Miller 1981).

\section{Results and Discussion}

\section{Antimicrobial effectiveness of chitosan against C. perfringens}

We investigated the inhibition of $C$. perfringens spore germination and outgrowth by the biopolymer chitosan during abusive chilling of cooked ground beef and turkey obtained from a retail store. Figure 2 shows the programmed and observed temperature profiles of the products for the $12,15,18$, and $21 \mathrm{~h}$ exponential chill rates. The 4 temperature profiles represent extended chilling rates relative to the USDA/FSIS compliance guidelines for cooling of cooked, uncured meat and poultry products (USDA/FSIS 2001). The use of a water bath to generate the desired product temperature profiles is highly reproducible and can be used in future validation studies or for evaluation of microbiological safety of much larger quantities of meat products in meat processing operations.

Table 1 shows that chilling of ground beef resulted in germination and outgrowth of $C$. perfringens spores. Specifically, in the control samples without chitosan, cooling from 54.4 to $7.2^{\circ} \mathrm{C}$ in $12,15,18$, or $21 \mathrm{~h}$, resulted in $4.21,4.51,5.03$, and $4.70 \log _{10} \mathrm{CFU} / \mathrm{g}$ increases, respectively, in C. perfringens populations of the ground beef. The corresponding increases for ground turkey were 5.27, 4.52, 5.11, and $5.38 \log _{10} \mathrm{CFU} / \mathrm{g}$.

Addition of chitosan to meat or turkey resulted in concentrationand time-dependent inhibition of growth of spores. At 3\%, chitosan reduced by 4 to $5 \log _{10} \mathrm{CFU} / \mathrm{g}$ C. perfringens spore germination and outgrowth during exponential cooling of the cooked beef in 12, 15, or $18 \mathrm{~h}(P \leq 0.05)$. The final $C$. perfringens population densities in

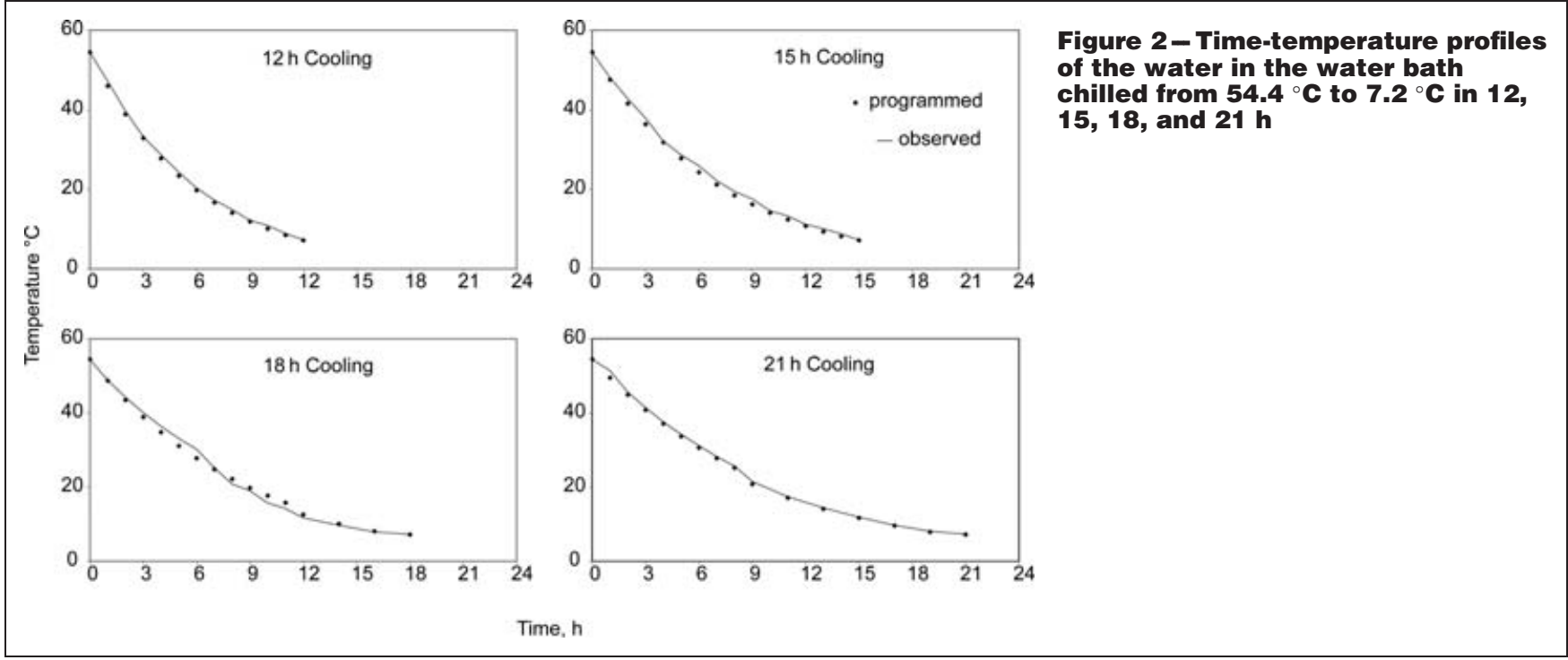

Table 1 - Mean log CFU/g populations of $C$. perfringens in cooked ground beef and turkey containing chitosan immediately after heat treatment (cook; $60^{\circ} \mathrm{C}$ in $1 \mathrm{~h}$ ), and following cooling (chill) from $54.4{ }^{\circ} \mathrm{C}$ to $7.2{ }^{\circ} \mathrm{C}$ exponentially in $12,15,18$, or $21 \mathrm{~h}$

\begin{tabular}{|c|c|c|c|c|c|c|c|c|}
\hline & \multicolumn{2}{|c|}{12 h Chill } & \multicolumn{2}{|c|}{15 h Chill } & \multicolumn{2}{|c|}{18 h Chill } & \multicolumn{2}{|c|}{21 h Chill } \\
\hline & Cook & Chill & Cook & Chill & Cook & Chill & Cook & Chill \\
\hline \multicolumn{9}{|c|}{ Ground beef } \\
\hline Control & $2.14(0.034)$ & $6.35(0.025)$ & $3.29(0.300)$ & $7.80(0.153)$ & $3.23(0.170)$ & $8.26(0.357)$ & $2.86(0.091)$ & $7.56(1.061)$ \\
\hline \multicolumn{9}{|c|}{ Chitosan (\%) } \\
\hline 0.5 & $2.23(0.042)$ & $4.31(0.057)^{b}$ & $3.27(0.121)$ & 7.77 (0.033) & $3.18(0.016)$ & $7.81(0.089)$ & $3.05(0.044)$ & 6.849).618) \\
\hline 1 & $2.43(0.018)^{a}$ & $4.37(1.269)^{\mathrm{b}}$ & $3.47(0.096)$ & $7.10(0.574)$ & $3.20(0.108)$ & $7.87(0.423)$ & $2.82(0.140)$ & $7.21(0.106)$ \\
\hline 2 & $2.72(0.003)^{\mathrm{a}}$ & $3.44(0.000)^{b}$ & $3.50(0.138)$ & $5.59(0.503)^{b}$ & $3.27(0.097)$ & $6.20(0.404)^{b}$ & $3.06(0.189)$ & $6.02(0.080)^{\mathrm{b}}$ \\
\hline 3 & $2.96(0.069)^{a}$ & $3.22(0.147)^{\mathrm{b}}$ & $3.61(0.061)$ & $3.60(0.108)^{b}$ & $3.47(0.124)$ & $3.61(0.275)^{b}$ & $3.31(0.069)$ & $5.59(0.392)^{b}$ \\
\hline \multicolumn{9}{|c|}{ Ground turkey } \\
\hline Control & $2.42(0.432)$ & $7.69(0.067)$ & $3.25(0.190)$ & $7.77(0.266)$ & $3.01(0.224)$ & $8.12(0.330)$ & $2.33(0.494)$ & $7.71(0.776)$ \\
\hline \multicolumn{9}{|c|}{ Chitosan (\%) } \\
\hline 0.5 & $2.34(0.007)$ & $3.27(0.269)^{\mathrm{b}}$ & $2.93(0.180)$ & $7.55(0.044)$ & $2.80(0.140)$ & $7.80(0.079)$ & $2.49(0.104)$ & $6.46(1.145)^{\mathrm{b}}$ \\
\hline 1 & $2.47(0.021)$ & $3.22(0.358)^{b}$ & $3.25(0.185)$ & $6.39(0.340)^{b}$ & $2.96(0.279)$ & 7.64 (0.232) & $3.06(0.240)$ & $6.59(0.806)^{b}$ \\
\hline 2 & $2.74(0.011)$ & $2.96(0.224)^{b}$ & $3.15(0.053)$ & $3.65(0.254)^{b}$ & $3.20(0.125)$ & $5.08(0.760)^{b}$ & $3.11(0.250)$ & $6.29(0.808)^{b}$ \\
\hline 3 & $2.49(0.044)$ & $2.91(0.288)^{b}$ & $3.47(0.017)$ & $3.41(0.137)^{b}$ & $3.41(0.084)$ & $3.26(0.511)^{b}$ & $3.49(0.080)^{a}$ & $5.14(0.309)^{b}$ \\
\hline
\end{tabular}

Values are averages from 2 separate experiments each in duplicate \pm standard deviations shown in parentheses.

a Significantly greater than the corresponding control at $P<0.05$ by Dunnett's test.

b Significantly less than the corresponding control at $P<0.05$ by Dunnett's test. 
beef samples with added $3 \%$ chitosan after 12,15 , or $18 \mathrm{~h}$ exponential chill rates ranged from 3.22 to $3.61 \log _{10} \mathrm{CFU} / \mathrm{g}$. The reduction was significantly lower $(P<0.05)$ at a chilling time of $21 \mathrm{~h}$, only about $2 \log _{10} \mathrm{CFU} / \mathrm{g}$, that is, $7.56 \log _{10} \mathrm{CFU} / \mathrm{g}$ (unsupplemented) compared with $5.59 \log _{10} \mathrm{CFU} / \mathrm{g}$ (3\% chitosan). The results suggest that incorporation of $3 \%$ chitosan into ground beef or turkey may reduce the potential risk of $C$. perfringens spore germination and outgrowth during abusive chilling rates of 12,15 , or $18 \mathrm{~h}$. The antimicrobial effects of adding corresponding amounts of chitosan to ground turkey were generally similar to those observed with ground beef (Table 1).

Table 1 also shows that for the beef and turkey "cook" data, 3 of the values for the $12 \mathrm{~h}$ chill and 1 value for the $21 \mathrm{~h}$ chill are higher than the corresponding controls. We have no apparent explanation for these results except to suggest that they may be due to chance and/or to the heterogeneity of the test substances.

\section{Mechanisms of antimicrobial effects}

The main mechanism that appears to govern the bacteristatic and bactericidal effects of chitosan appears to involve binding of its positively charged amino $\left(-\mathrm{NH}_{3}{ }^{+}\right)$groups (Figure 1) to negatively charged carboxylate $\left(-\mathrm{COO}^{-}\right)$groups located on the surface of the bacterial cell membranes (Rabea and others 2003). Such electrochemical binding can alter the distribution of negative and positive charges on the surfaces of the cell membranes, leading to weakening and/or disruption of the membranes followed by leakage of cell components. This mechanism is supported by electron microscopy studies that showed that the polymer binds to and weakens the outer membrane of bacteria (Helander and others 2001) as well as by atomic force microscopy studies which indicate that chitosan nanoparticles induced disruption of cell membranes and leakage of cytoplasm of Salmonella choleraesius organisms (Qi and others 2004).

Because chitosan is also reported to strongly chelate toxic and essential metal ions (Friedman and Waiss 1972; Masri and others 1974; Piron and Domard 1998; Jeon and Park 2005), it is also likely that binding of chitosan to trace elements, such as ferric and zinc ions that the bacteria need for growth, may contribute to its antimicrobial action (Rabea and others 2003). The $\mathrm{pH}$ of the microenvironment in which chitosan operates determines the relative concentrations (ratios) of unprotonated and protonated amino groups which are governed by the equilibrium:

$$
\begin{aligned}
\text { Chitosan } & -\mathrm{NH}_{2} \text { (unprotonated) }+\mathrm{H}^{+} \leftrightarrow \text { Chitosan } \\
& -\mathrm{NH}_{3}{ }^{+} \text {(protonated) }
\end{aligned}
$$

The antimicrobial effectiveness of chitosan appears to be highest below $\mathrm{pH} 6$ where the protonated form predominates and where chitosan is most soluble. By contrast, only the unprotonated form can chelate essential metal ions. These considerations suggest that depending on $\mathrm{pH}$, different mechanisms may operate in different food categories and that lowering the internal $\mathrm{pH}$ of meat may enhance the antimicrobial activity of chitosan. The internal $\mathrm{pH}$ values of the ground meat and turkey used in this study were 6.25 and 6.46, respectively.

\section{Conclusions}

$\mathrm{T}$ he results of the present study demonstrate for the 1st time that the widely used food additive chitosan adequately restricted, in a concentration-dependent manner, growth of $C$. perfringens spores in both ground meat and ground turkey up to a cooling time of $18 \mathrm{~h}(P \leq 0.05)$. The antimicrobial effectiveness was lower at the cooling time of $21 \mathrm{~h}$ than at the shorter time periods. These findings suggest that chitosan-containing meat and poultry products may benefit microbial food safety and the consumer. It would be of interest to find out whether low levels of chitosan in combination with low levels of organic acids and salts, which are reported at high concentrations to protect meat against C. perfringens (Juneja and Marmer 1998; Thippareddi and others 2003; Zaika 2003; Juneja and Thippareddi 2004; Sabah and others 2004), will exhibit additive or synergistic antimicrobial effects in meat and poultry matrices.

\section{Acknowledgments}

A contribution of the University of Nebraska Agricultural Research Division, supported in part by funds provided through USDACSREES under agreement 25-6231-0078-001 and the Hatch Act.

\section{References}

Anonymous. 2001. GRAS notices received in 2001. Available from: http://www.cfsan fda.gov/ rdb/opa-gn01.html. US Food and Drug Administration, Center for Food Safety and Applied Nutrition, Office of Food Additive Safety.

Bean NH, Griffin PM. 1990. Foodborne disease outbreaks in the United States, 19731987: pathogens, vehicles, and trends. J Food Prot 53:804-17.

Bryan FL. 1988. Risks associated with vehicles of foodborne pathogens and toxins. Food Prot 51:498-508.

Bryan FL, McKinley TW. 1979. Hazard analysis and control of roast beef preparation in foodservice establishments. J Food Prot 42:4-18.

[CDC] Centers for Disease Control and Prevention. 2000. Surveillance for foodbornedisease outbreaks-United States, 1993-1997. MMWR 49:1-58.

Chen YM, Chung YC, Wang LW, Chen KT, Li SY. 2002. Antibacterial properties of chitosan in waterborne pathogen. J Environ Sci Health A Tox Hazard Subst Environ Eng 37:1379-90.

Darmadji P, Izumimoto M. 1994. Effect of chitosan in meat preservation. Meat Sci 38:243-54

Devlieghere F, Vermeulen A, Debevere J. 2004. Chitosan: antimicrobial activity, interactions with food components and applicability as a coating on fruit and vegetables. Food Microbiol (London) 21:703-14.

Friedman M, Waiss SJ Jr. 1972. Mercury uptake by selected agricultural products and byproducts. Environ Sci Technol 6:457-8.

Helander IM, Nurmiaho-Lassila EL, Ahvenainen R, Rhoades J, Roller S. 2001. Chitosan disrupts the barrier properties of the outer membrane of gram-negative bacteria. Int J Food Microbiol 71:235-44.

Hirano S. 1997. Applications of chitin and chitosan in the ecological and environmental fields. In: Goosen MFA, editor. Applications of chitin and chitosan. Lancaster, Pa.: Technomic Publishing Co., Inc. p 31-54.

Jeon C, Park KH. 2005. Adsorption and desorption characteristics of mercury(II) ions using aminated chitosan bead. Water Res 39:3938-44.

Jumaa M, Furkert FH, Muller BW. 2002. A new lipid emulsion formulation with high antimicrobial efficacy using chitosan. Eur J Pharm Biopharm 53:115-23.

Juneja VK, Marmer BS. 1998. Thermal inactivation of Clostridium perfringens vegetative cells in ground beef and turkey as affected by sodium pyrophosphate. Food Microbiol 15:281-7.

Juneja VK, Thippareddi H. 2004. Inhibitory effects of organic acid salts on growth of Clostridium perfringens from spore inocula during chilling of marinated ground turkey breast. Int J Food Microbiol 93:155-63.

Juneja VK, Call JE, Miller AJ. 1993. Evaluation of methylxanthines and related com pounds to enhance Clostridium perfringens sporulation using a modified Duncan and Strong medium. J Rapid Meth Automat Microbiol 2:203-18.

Kalinowski RM, Tompkin RB, Bodnaruk PW, Pruett WP Jr. 2003. Impact of cooking cooling, and subsequent refrigeration on the growth or survival of Clostridium perfringens in cooked meat and poultry products. J Food Prot 66:1227-32.

Kim KW, Thomas RL, Lee C, Park HJ. 2003. Antimicrobial activity of native chitosan, degraded chitosan, and $O$-carboxymethylated chitosan. J Food Prot 66:1495-8.

Knowles J, Roller S. 2001. Efficacy of chitosan, carvacrol, and a hydrogen peroxidebased biocide against foodborne microorganisms in suspension and adhered to stainless steel. J Food Prot 64:1542-8.

Masri MS, Reuter FW, Friedman M. 1974. Binding of metal cations by natural substances. J Appl Polym Sci 18:675-81.

Miller RG Jr. 1981. Simultaenous statistical inference. New York: Springer-Verlag p 67-70

Nychas G-JE, Skandamis PN, Tassou CC. 2003. Antimicrobials from herbs and spices. In: Roller S, editor. Natural antimicrobials for the minimal processing of foods. Cambridge, England: Woodhead Publishing Limited. p 176-200.

Okawa Y, Kobayashi M, Suzuki S, Suzuki M. 2003. Comparative study of protective effects of chitin, chitosan, and $N$-acetyl chitohexaose against Pseudomonas aeruginosa and Listeria monocytogenes infections in mice. Biol Pharm Bull 26:902-4.

Ouattara B, Simard RE, Piette G, Begin A, Holley RA. 2000. Inhibition of surface spoilage bacteria in processed meats by application of antimicrobial films prepared with chitosan. Int J Food Microbiol 62:139-48.

Piron E, Domard A. 1998. Interaction between chitosan and uranyl ions. Part 2. Mechanism of interaction. Int J Biol Macromol 22:33-40.

Pranoto Y, Rakshit SK, Salokhe VM. 2005. Enhancing antimicrobial activity of chitosan films by incorporating garlic oil, potassium sorbate and nisin. LebensmittelWissenschaft und-Technologie 8:859-65.

Qi L, Xu Z, Jiang X, Hu C, Zou X. 2004. Preparation and antibacterial activity of chitosan nanoparticles. Carbohydr Res 339:2693-700. 
Rabea EI, Badawy ME, Stevens CV, Smagghe G, Steurbaut W. 2003. Chitosan as antimicrobial agent: applications and mode of action. Biomacromolecules 4: 1457-65.

Rhoades J, Roller S. 2000. Antimicrobial actions of degraded and native chitosan against spoilage organisms in laboratory media and foods. Appl Environ Microbiol 66:80-6.

Roller S. 2003. Chitosan: New food preservative or laboratory curiosity. In: Roller S, editor. Natural antimicrobials for the minimal processing of foods. Cambridge England: Woodhead Publishing Limited. p 158-75.

Sabah JR, Juneja VK, Fung DY. 2004. Effect of spices and organic acids on the growth of Clostridium perfringens during cooling of cooked ground beef. J Food Prot 67: 1840-7.

Sagoo S, Board R, Roller S. 2002. Chitosan inhibits growth of spoilage micro-organisms in chilled pork products. Food Microbiol 19:175-82.

Schwab AH, Leininger HV, Powers EM. 1984. Media, reagents, and strains. In Speck ML, editor. Compendium of methods for the microbiological examination of foods. 2nd ed. Wash., DC: American Public Health Assn., Inc. p 788897.

Shahidi F, Arachchi JKV, Jeon Y-J. 1999. Food applications of chitin and chitosans. Trends Food Sci. Technol 10:37-51.
Shepherd R, Reader S, Falshaw A. 1997. Chitosan functional properties. Glycoconj J 14:535-42.

Singla AK, Chawla M. 2001. Chitosan: some pharmaceutical and biological aspects-an update. J Pharm Pharmacol 53:1047-67.

Taormina PJ, Bartholomew GW, Dorsa WJ. 2003. Incidence of Clostridium perfringens in commercially produced cured raw meat product mixtures and behavior in cooked products during chilling and refrigerated storage. J Food Prot 66:72-81.

Thippareddi H, Juneja VK, Phebus RK, Marsden JL, Kastner CL. 2003. Control of Clostridium perfringens germination and outgrowth by buffered sodium citrate during chilling of roast beef and injected pork. J Food Prot 66:376-81.

Tsai G-J, Su W-H, Chen H-C, Pan C-L. 2002. Antimicrobial activity of shrimp chitin and chitosan from different treatments and applications of fish preservation. Fish Sci (Tokyo) 68:170-7.

[USDA/FSIS] U.S. Dept. of Agriculture/Food Safety and Inspection Service. 2001. Draft compliance guidelines for ready-to-eat meat and poultry products. Fed Regist 66. 10 May 2001.

Zaika LL. 2003. Influence of $\mathrm{NaCl}$ content and cooling rate on outgrowth of Clostridium perfringens spores in cooked ham and beef. J Food Prot 66:1599-603. 